\title{
Annuity costs in the UK
}

Received: 28th February, 2000

\section{Mamta Murthi}

is with the Centre for History and Economics at Kings College, Cambridge University. Her research interests include economic demography, social security reform and poverty. She holds a PhD from Oxford University and has worked at the World Bank and the University of Sussex.

\section{J. Michael Orszag*}

is on the faculty of Birkbeck College, London. His research interests include pensions and personnel economics. He holds a $\mathrm{PhD}$ from the University of Michigan.

\section{Peter R. Orszag}

is president of Sebago Associates, a public policy consulting firm. He was previously Special Assistant to the President in the Clinton White House, where his remit included social security issues. He holds a PhD from the London School of Economics.

\begin{abstract}
This paper summarises some results from a recent research project on UK annuity costs and market behaviour. Annunity costs are decomposed into two components: selection effects and pure administrative costs. We find that selection effects account for the majority - perhaps one-half to two-thirds - of total annuity costs for the typical individual, while pure administrative cost loadings are relatively low. Our results are sensitive to mortality assumptions, but nevertheless also suggest that inappropriate portfolio selection (gilt-backed conventional annuities) represents a more substantial barrier to wider use of annuities than does high cost loadings.
\end{abstract}

Keywords: UK annuity costs; compulsory annuities; value for money; expected present discounted value (EPDV); money's worth ratios (MWR)

\section{Introduction}

Annuity yields in the UK have been falling in tandem with interest rates for the past few years. The reduction in annuity yields, in turn, has generated a growing demand for greater flexibility with respect to annuitisation. Whether such increased flexibility represents sound public policy depends at least in part on the charges imposed on annuities. Yet despite anecdotal evidence of consumer unrest about the value for money of annuities, charges on annuities have not received substantial attention. ${ }^{1}$

This paper summarises some results from a recent study of ours on the cost of annuities in the UK. ${ }^{2}$ The study was part of a wider World Bank project on annuities markets throughout the world.

\section{Value for money and annuities: Overview}

Retirees who are concerned about outliving their savings have an incentive to purchase an annuity, which provides a payment (often on a monthly basis) for every year the annuitant (or the annuitant's dependant) is alive, in exchange for a lump-sum payment up front to the annuity company. For those who have accumulated retirement funds, the purchase of an annuity thus provides insurance against exhausting the account 
before death. But such insurance is costly for two reasons: a selection cost and an administrative cost.

Selection arises in the annuities market because people with longer-than-average life expectancies are more likely to purchase annuities, and more likely to purchase larger annuities, than people with shorter-than-average life expectancies. The insurance companies that sell annuity policies consequently price them based on the longer life expectancies of the annuitants. ${ }^{3}$ A typical person (with average life expectancy) must therefore pay a higher price for an annuity than would be justified based on average life expectancy.

To see how this works, assume that a typical 65-year-old male in the population has a life expectancy of 15 years. Those who purchase annuities, however, have an average life expectancy of 20 years. Then consider an insurance company selling an annuity that will pay out $\mathcal{E} 10,000$ per year. If the insurance company bases the annuity price on the average life expectancy in the population, it will effectively only charge for 15 years. But the people actually buying annuities have a longer average life expectancy, so the insurance company would then lose money on the sales (it would pay out the $\mathcal{f}^{10,000}$ for more years than it had assumed in pricing the annuity). The insurance company will therefore price the annuity to reflect the 20-year average life expectancy of the people who purchase annuities. For someone with the average 15-year life expectancy, the price of the annuity is thus higher (the selection cost) than could be justified based on that average population life expectancy.

The second component of annuity costs consists of the administrative costs the annuity provider bears; such costs cover expenses such as marketing, commissions to agents, investment costs, overhead, capital requirements and profits.

Our analysis of these two costs of annuities reached the following conclusions:

- First, the overall annuity cost loading is roughly $10-15$ per cent of the account value for the typical individual. That is, for a typical individual, we find that the expected cost of annuitising an account worth $£ 10,000$ would be approximately 1,000 . (Details on how the expected cost is computed are described below.) We also find this figure has not changed much since 1994.

- Secondly, half to two-thirds of the overall cost loading is due to selection effects. The pure administrative cost loading on annuities is thus no more than 5 per cent of the value of the account. The implication is that purchasing an annuity involves low costs for the typical annuitant, since the typical annuitant does not bear any selection costs, even if it involves higher costs for the typical person.

Other researchers have reached similar conclusions for the annuities market in the USA. They find that the majority of annuity costs are accounted for by selection rather than 'traditional' cost loadings.

Whether these costs are 'high' or 'low' is in the eye of the beholder. But whatever the resolution of that semantic debate, it is clear that annuitisation costs are significantly lower than personal pension charges in the UK. There are a variety of explanations for this:

- Sales commissions are low relative to other financial products.

- Annuities are commoditised, so it is easy for consumers or advisers to compare rates across products. 
- The annuity amounts are relatively large, so customers have an incentive to search extensively.

- The lack of availability of fine-grained mortality data limits the ability of providers to cherry-pick customers.

- Economies of scale and other benefits to providers from attracting market share in a growing market reduce prices to consumers.

- For providers, annuities are a useful balance against life insurance liabilities, so that they are willing to sell them at very competitive prices.

- Once sold, annuities are relatively easy to administer, and hence administrative costs are likely to be low.

- Pension annuities purchases in the UK are irreversible, so providers do not bear lapse risk.

Despite the high value for money of annuities relative to personal pensions, we also observed a number of important imperfections in the annuities market. These imperfections are explored in more detail below.

\section{Value for money of annuities: Theoretical framework}

This section provides more details on how to compute the cost of annuitisation. As mentioned above, an annuity provides a stream of income until one's death in return for an initial premium. A standard way of evaluating the value for money of such a contract is to compare the expected present discounted value (EPDV) of the future income stream with the initial premium paid. The ratio of the EPDV to the purchase price is known as the money's worth ratio (MWR). For an individual deciding on which type of annuity to buy, an annuity with a higher MWR provides greater value for money. In general, the MWR depends on purchase price, the size of the future income flow, the individual's subjective assessment of mortality risk, and his or her rate of time preference.

The MWR would be equal to 1.0 if the annuity was 'actuarially fair'. In that case, the expected discounted value of the income stream from the annuity would just equal the lump-sum turned over to pay for the annuity.

In practice, however, we are likely to observe ratios that are less than unity. In other words, for every $f 1$ of initial premium, the average individual can expect to receive less than $\mathcal{E}^{1}$ 's worth of future income. The difference is accounted for by a number of factors, including selection costs and the administrative costs of insurance companies (including marketing, commissions to agents, investment costs, overhead, and capital requirements).

A crucial issue is then how to split the total cost of purchasing an annuity into the selection component and the administrative cost component. The answer is that we first compute the MWR using the population's life expectancy. The difference between this MWR and 1.0 will reflect both administrative and selection costs. We then compute the MWR using the annuitants' life expectancy. The difference between that MWR and 1.0 will reflect only the administrative costs, since the selection effect is eliminated by using the annuitants' life expectancy in the calculations. By comparing the MWRs using the population life expectancy to the MWRs using the annuitant life expectancy, we can therefore break the total cost into its two components.

It is worth making two points about selection in annuities markets. First, selection effects may arise both from socio-economic differentials in mortality 
as well as from asymmetric information. To the extent that insurers in the UK rarely use socio-economic factors in pricing, the observed socio-economic differentials could well be due mostly to asymmetric information arising from the costs of verifying individuals' asset and income data. But a precise accounting for how much of the total selection effect is due to asymmetric information and how much is due to objective unpriced mortality differentials among risk classes remains unclear. Secondly, selection costs are a financial loss only relative to the actuarially fair annuity for that typical individual; they should not be used to suggest that the annuitant suffers a utility loss, nor do they provide a metric of the social welfare losses from annuitisation. $^{4}$

\section{Value for money of annuities: Results}

In our research, we focused on the compulsory annuities market (which handles those purchasing annuities from pensions) and considered both single and joint life annuities, by age and sex. ${ }^{5}$ We examined three types of annuities: level, escalating and RPI-indexed annuities:

- A level annuity pays the same nominal sum each period until the end of the individual's life.

- Escalating annuities raise the payout at a fixed rate, usually once a year. Annuities that escalate at both 3 per cent p.a. and 5 per cent p.a. are common in the UK.

- RPI-indexed annuities raise the amount in line with the retail price index, again usually once a year. Such indexed annuities thus provide insurance against inflation.

Compared to level annuities, escalating and RPI-indexed annuities provide greater value in the later years of life. Those who expect to live long might thus favour them. We also know that indexed annuities tend to be for larger amounts than other types of annuities. Unfortunately, we do not have data on life expectancies by type of annuity, so we cannot examine whether selection is significantly different in these three markets.

We consider an individual who is contemplating the purchase of a single or joint-life annuity from one of the main life insurance companies in the UK. Our information on annuity rates is from Investment Intelligence, a financial services company, which provides annuity data by age, gender, market, type of annuity, and policy size. ${ }^{6}$ The data cover the 15-20 major providers in the market. ${ }^{7}$

As explained above, we examine the EPDV from the point of view of both the average person and the average annuitant. We also make various assumptions about interest rates.

\section{Annuity pay-outs per year}

Table 1 provides a summary of market rates for level annuities on 30th April, 1999. The table records the annual payment offered against a purchase price of $£ 10,000$ by age and gender. We report information separately on open-market options and compulsory purchase annuities, and consider the market average (median), the fifth best rate in the market, and the top rate. ${ }^{8}$

From the top panel, we see that a 65-year-old man purchasing a typical $\mathcal{E}_{10,000}$ level annuity in the market for open market options could expect to receive an annual payment of $£ 851$ for life. A woman of the same age could expect to receive $£ 749$ for life, or about 12 per cent less, on account of higher longevity. A 65-year-old couple (where 
Table 1: Annuity payouts per year by age and sex, April 1999

\begin{tabular}{|c|c|c|c|}
\hline & Age 65 & Age 70 & Age 75 \\
\hline \multicolumn{4}{|l|}{ Open market options } \\
\hline \multicolumn{4}{|l|}{ Industry average } \\
\hline Males & 851.0 & 1013 & 1235.8 \\
\hline Females & 749.0 & 855.0 & 1045.1 \\
\hline Joint and survivor & 623.9 & 687.5 & 782.8 \\
\hline \multicolumn{4}{|l|}{ Fifth best } \\
\hline Males & 868.0 & 1031.0 & 1271.8 \\
\hline Females & 761.3 & 882.5 & 1063.4 \\
\hline Joint and survivor & 632.0 & 707.0 & 799.0 \\
\hline \multicolumn{4}{|l|}{ Top rate } \\
\hline Males & 908.4 & 1100.3 & 1371.8 \\
\hline Females & 778.4 & 915.8 & 1132.3 \\
\hline Joint and survivor & 662.0 & 727.6 & 835.0 \\
\hline \multicolumn{4}{|l|}{ Compulsory purchase } \\
\hline \multicolumn{4}{|l|}{ Industry average } \\
\hline Males & 850.1 & 1003 & 1221.0 \\
\hline Females & 751.2 & 867.0 & 1050.0 \\
\hline Joint and survivor & 625.9 & 690.0 & 789.8 \\
\hline \multicolumn{4}{|l|}{ Fifth best } \\
\hline Males & 868.0 & 1031.0 & 1271.8 \\
\hline Females & 761.5 & 882.5 & 1063.4 \\
\hline Joint and survivor & 632.0 & 707.0 & 799.0 \\
\hline \multicolumn{4}{|l|}{ Top rate } \\
\hline Males & 925.8 & 1117.8 & 1389.7 \\
\hline Females & 790.6 & 932.8 & 1149.4 \\
\hline Joint and survivor & 662.0 & 737.8 & 850.8 \\
\hline
\end{tabular}

Source: The data are provided by Investment Intelligence. Each entry indicates the yearly income in pounds accruing from a level policy, with no guarantee period, payable monthly in advance, and is based on a purchase price of $£ 10,000$. The rates for the joint life annuities assume that the man is the specified age (65, $70,75)$ and the woman is five years younger, and there is no reduction on the first death.

the man is 65 and the woman 60) would receive $£ 623.9$ a year for life, or about 27 per cent less than a single male.

Not surprisingly, annuity payments generally increase with age. Since the pay-out starts later, we would expect the payment per year to be higher. Thus, a 70-year-old man would receive an annual payout of $\mathcal{E} 1,013$ a year, almost 20 per cent more than a man five years his junior. For women, age also raises the annual payment, but by less than for men. A 70-year-old woman could expect to receive around 14 per cent more than a woman five years her junior. For joint and survivor annuities, in which a surviving spouse is entitled to continued payments after the death of the annuitant, the increase is even lower. A 70 -year-old couple (where the man is 70 and the woman 65) would receive about
10 per cent more than a couple five years younger. Table 1 also gives an indication of the degree of dispersion at the upper end of the market for open market options. In general, there is a small difference (1-2 per cent) between the average rate and the fifth best rate. Differences between the average and the top rate are greater, of the order of 6-8 per cent. This suggests that the top half of the market tends to be fairly clustered, and the benefits of shopping around for the best rate in this segment of the market do not vary significantly by age and sex.

Table 1 further suggests that annuity rates do not vary significantly between open market options and compulsory purchase annuities. Indeed, the rates in the two markets are fairly close, and the pattern of dispersion is also broadly 
Table 2: Money's worth ratios for different types of annuities in April 1999

\begin{tabular}{|c|c|c|c|c|c|c|}
\hline & \multicolumn{3}{|c|}{$\begin{array}{c}\text { Population life tables } \\
3 \text { per cent }\end{array}$} & \multicolumn{3}{|c|}{ Annuitant life tables (PML) } \\
\hline & \multicolumn{6}{|c|}{ Open market options } \\
\hline \multicolumn{7}{|c|}{ Males } \\
\hline 65 & 0.897 & 0.886 & 0.801 & 0.966 & 0.971 & 0.878 \\
\hline 70 & 0.875 & 0.852 & 0.799 & 0.955 & 0.947 & 0.887 \\
\hline 75 & 0.850 & 0.820 & 0.776 & 0.940 & 0.922 & 0.871 \\
\hline \multicolumn{7}{|c|}{ Females } \\
\hline 65 & 0.910 & 0.894 & 0.798 & 0.957 & 0.954 & 0.850 \\
\hline 70 & 0.870 & 0.862 & 0.796 & 0.932 & 0.941 & 0.867 \\
\hline 75 & 0.871 & 0.849 & 0.791 & 0.942 & 0.934 & 0.871 \\
\hline \multicolumn{7}{|c|}{ Joint and survivor } \\
\hline 65 & 0.940 & 0.920 & 0.811 & 0.971 & 0.965 & 0.849 \\
\hline 70 & 0.912 & 0.893 & 0.798 & 0.956 & 0.952 & 0.849 \\
\hline \multirow[t]{2}{*}{75} & 0.883 & 0.854 & 0.767 & 0.943 & 0.923 & 0.833 \\
\hline & \multicolumn{6}{|c|}{ Compulsory purchase } \\
\hline \multicolumn{7}{|c|}{ Males } \\
\hline 65 & 0.896 & 0.884 & 0.807 & 0.965 & 0.962 & 0.833 \\
\hline 70 & 0.867 & 0.852 & 0.799 & 0.946 & 0.947 & 0.867 \\
\hline 75 & 0.840 & 0.821 & 0.766 & 0.928 & 0.923 & 0.871 \\
\hline \multicolumn{7}{|c|}{ Females } \\
\hline 65 & 0.913 & 0.899 & 0.821 & 0.956 & 0.959 & 0.915 \\
\hline 70 & 0.882 & 0.863 & 0.796 & 0.944 & 0.942 & 0.867 \\
\hline 75 & 0.874 & 0.852 & 0.807 & 0.946 & 0.938 & 0.887 \\
\hline \multicolumn{7}{|c|}{ Joint and survivor } \\
\hline 65 & 0.943 & 0.928 & 0.813 & 0.974 & 0.973 & 0.852 \\
\hline 70 & 0.915 & 0.902 & 0.803 & 0.959 & 0.961 & 0.854 \\
\hline 75 & 0.891 & 0.876 & 0.801 & 0.951 & 0.946 & 0.870 \\
\hline
\end{tabular}

Notes: Each entry shows the ratio of the expected present discounted value of the annuity income stream as a proportion of purchase price $(£ 10,000)$. Calculations use the average annuity rate in the market and the term structure of yields on UK government bonds.

similar. The best rates in the compulsory purchase market, however, appear higher than in the market for open market options.

\section{Money's worth ratios}

Our next step is to examine the MWR relationship between the annuity payouts listed in Table 1 and their purchase price. We estimated MWRs by sex and age, for both single and joint-life annuities, and consider the market for open market options and compulsory purchase annuities separately.

In Table 2, we compare the MWR for three types of annuities: level, 3 per cent escalating, and indexed (real). The table highlights our principal conclusion: the MWR using the annuitant life expectancy is typically 0.95 or higher for level and 3 per cent escalating annuities, relative to approximately $0.85-0.90$ when the population life expectancy is used. Comparison of the $0.85-0.90$ figure to the 0.95 figure thus indicates that roughly one-half to two-thirds of the cost of annuitising arises from selection effects, rather than pure administrative cost loading. Administrative cost loadings by themselves are relatively low, perhaps 5 per cent of the value of an account to be annuitised, as the MWR using the annuitant life tables suggests $(1.0-0.95=0.05)$.

Table 2 also indicates that indexed annuities offer significantly lower value for money than level annuities. In 
Table 3: Trends in value for money of open market options during the 1990s Ex-post rates

\begin{tabular}{|c|c|c|c|c|}
\hline & $\begin{array}{l}\text { Population life tables } \\
\text { October } 1990\end{array}$ & October 1994 & October 1998 & April 1999 \\
\hline \multicolumn{5}{|l|}{ Males } \\
\hline 65 & 0.996 & 0.921 & 0.932 & 0.905 \\
\hline \multirow[t]{2}{*}{70} & 0.973 & 0.917 & 0.913 & 0.881 \\
\hline & \multicolumn{4}{|c|}{ Annuitant life tables (PML) } \\
\hline Males & & & & \\
\hline 65 & 1.000 & 0.959 & 0.955 & 0.968 \\
\hline 70 & 0.981 & 0.955 & 0.981 & 0.949 \\
\hline
\end{tabular}

Notes: Each entry shows the ratio of the expected present discounted value of the annuity income stream as a proportion of purchase price. Calculations use the average annuity rate in the market and the term structure of yields on UK government bonds at the time. The rates are for level annuities, payable in advance, with a five-year guarantee. Note that the figures are ex-post rates that make mortality improvement assumptions that were not in use when the annuities were priced.

general, there is a difference in value of around 10 pence in the $\mathcal{E}$, between level and real annuities. The high cost of the inflation insurance offered by indexed annuities may help to explain why they have not proven to be popular. ${ }^{9}$ It would be hard to ascribe the higher cost purely to the cost of bearing inflation risk, since insurers can avoid some, if not all, of this risk through inflation-indexed bonds. A part of the explanation may lie in selection effects that we cannot detect (since we do not have life expectancy by type of product, and since real annuities are likely to be favoured by those who expect to live especially long).

Finally, we can examine the change in MWRs over time. Table 3 suggests that at least for the past five years (1994 onwards), there has been no significant trend in the value for money for annuities. This holds whether we use population or annuitant life tables. ${ }^{10}$

\section{Conclusions}

This paper summarises our conclusions about the money's worth of annuities in the UK from our World Bank study on the topic. We find that the overall cost loading on an annuity is $10-15$ per cent and that between half and two-thirds of that cost arises from selection effects rather than administrative costs. Standard annuities thus have relatively low implicit administrative cost mark-ups relative to personal pensions and other financial products. In a sense, these relatively low costs are not surprising, given the commoditised nature of the standard annuity.

The conventional annuity is hence very much an excellent example of a CAT-standard commoditised product. At the same time, the simplicity of the product and its inflexible design may make it inappropriate for retired individuals who now have long investment horizons. ${ }^{11}$ We also find some imperfections in the annuities market, potentially including the MWR for inflation-indexed annuities.

\section{Acknowledgement}

The authors wish to thank (without implicating) numerous reviewers and others who have provided us with information and comments. We would also like to thank Amy Finkelstein for extensive discussions. We are grateful to Investment Intelligence (a division of the Research Department) and Thesys Ltd. for the use of their data, and particularly Yvonne Murray of Thesys for numerous clarifications.

\section{References}

1 Personal pension charges, on the other hand, have attracted attention because public policy has focused on the accumulation stage. Indeed, the personal pension 'mis-selling' episode has resulted in greater regulatory oversight of charges and the institution of 
compensation procedures for individuals who were missold pensions.

2 See http:www.pensions-research.org/annuities for our complete, technical paper on this subject.

3 Given the mandatory annuitisation rules in the UK, the selection effects occur both because of selection in who holds individual accounts during the accumulation phase and the timing of annuitisation.

4 For further discussion of the expected utility of purchasing an annuity see Mitchell, Poterba, O. J., Warshawsky, M. and Brown, J. (1999) 'New Evidence on the Money's Worth of Individual Annuities', NBER Working Paper No., 1977. Forthcoming in American Economic Review.

5 We ignore the issues of protected rights annuities by assuming the individual is contracted into SERPS. Because age-related SERPS rebates are capped at 9 per cent, older individuals close to retirement tend to be contracted in, so that there are not many people retiring today who need to purchase protected rights annuities.

6 In addition to these factors, the precise rate depends on payment frequency (monthly, semi-annually, or annually), whether payment is in advance or in arrears, whether there is a guarantee period, and, in the case of joint life annuities, the size of survivor benefits. We concentrate on policies where payment is monthly in advance, with no guarantee and no reduction in survivor benefits.

7 The exact number of providers in each market varies by type of annuity.
8 Payments are made monthly in advance and there is no guarantee period.

9 The annuity broker Annuity Bureau reports 83.5 per cent of its customers buy level annuities and only 5.3 per cent opt for any type of escalating annuity (see Peter Quinton, 'Good News for Innovators', Pensions Management, June 1999, p. 82). The proportion of the population purchasing level annuities may be even higher than these figures suggest because of the composition of the consumer base of the Annuity Bureau.

10 The MWRs for 1990, however, appear somewhat higher. Our guess is that the comparison with 1990 may be skewed because the use of mortality improvement factors was not prevalent until later; it would therefore not represent a genuine decline in the value for money since the start of decade. That explanation is also consistent with the ex-post losses on annuity contracts which has been a feature of the market.

11 For an examination of optimal investment strategies and product designs, see Kapur, S. and J. Michael Orszag (1999), 'A Portfolio Approach to Investment and Annuitization During Retirement', Draft: May 1999, available at http://www.pensions-research.org.

\section{Bibliography}

Poterba, J. and Warshawsky, M. (1999) 'The Costs of Annuitising Retirement Payments from Individual Accounts', NBER Working Paper 6918, January. 